\title{
'Pacific Destiny' and American Policy in Samoa, 1872-1899
}

\section{Stuart Anderson}

American involvement in Samoa in the late 19th Century constitutes one of the most extraordinary episodes in the diplomatic history of the United States. ${ }^{1}$ During a period of intense opposition to foreign entanglements and overseas expansion, the United States was embroiled in the affairs of a remote island group where American strategic interests were almost nonexistent and the American economic stake was insignificant. At a time when the expansive policies of William $\mathrm{H}$. Seward and Ulysses S. Grant were handily defeated in the Congress, the Alaska treaty was ridiculed, James G. Blaine's pan-Americanism ended in failure, and Hawaiian annexation remained a task for the future, the United States was ready to enter into agreements regarding Samoa that constituted, in a sense, the nation's first entangling alliance since the French treaty of $1778 . .^{2}$ Yet it is still far from clear what attracted American interest to Samoa. The standard diplomatic history textbooks offer no convincing explanation; all would seem to agree with Thomas A. Bailey that "there was something remarkable about the determination of the United States, ten years before the Spanish-American War, to go to the very brink of hostilities with Germany rather than yield negligible commercial and questionable strategic advantages in faraway Samoa." 3 Clearly the United States had no vital interests in the Samoan archipelago. Why she was so deeply involved in that part of the world for almost 30 years has remained, therefore, a mystery.

It is the contention of this essay that United States involvement in Samoa can be explained only in terms of the idea of America's Pacific destiny that existed in the minds of American policy makers. William

Stuart Anderson received his Ph.D. in American History from Claremont Graduate School, California in 1978. His major field of interest is I9th Century American foreign relations. 
H. Seward's vision of the future of the Pacific is familiar to most students of the history of American foreign relations. "The Pacific Ocean," the senator from New York told his colleagues in 1852 , "its shores, its islands, and the vast regions beyond, will become the chief theatre of events in the world's great hereafter."4 Long after Seward had passed from the scene, many Americans in positions of power continued to believe in his vision and to act on their belief. For a succession of Washington officials in the late igth Century, in both the executive and legislative branches of the government, Samoa, with its harbor of Pago Pago, occupied a conspicuous position in the prognosis of America's future in the Pacific. Samoa was important not for any present American interests there, but as a future outpost of an American military and commercial domain. For some, Samoa's chief importance was as a coaling station for merchantmen plying the trade routes to Asia and the South Pacific; for others, its importance was as a naval base for defense of this trade, as well as defense of the West Coast and the future isthmian canal. For all, however, Samoa's real value lay in the role it was to play in the not-too-distant future, when America had burst out of its insular shell and established itself as the paramount influence in the vast regions of the Pacific. When that time came, control of the Samoan Islands would be vital to the United States. It was for this reason that a succession of administrations in Washington struggled to maintain American influence in Samoa until the time came when the American public was ready to sanction American expansion there, and the acquisition of the wonderful harbor of Pago Pago.

Though the United States had had treaty relations with Samoa since $1839,{ }^{5}$ the archipelago was practically unknown in Washington until American commercial interests began to penetrate Samoa in the early 1870 s. $^{6}$ Already by 1872 , however, the Navy Department and the Grant administration were aware of Pago Pago's importance as a South Pacific harbor. A letter from Captain Wakeman, of the Webb steamship line, to his employer, William H. Webb, was forwarded to Secretary of the Navy George M. Robeson. Pago Pago, Captain Wakeman declared, was "the most perfectly land-locked harbor that exists in the Pacific Ocean." The Samoan Islands occupied a commanding position in the mid-Pacific, the captain said, "with control of the commerce of all the islands which are contiguous to this point," and with Australia and New Zealand practically at their doorstep. Wakeman believed that no other island group was better suited for a naval station and a coal depot for commercial vessels. The future of Samoa was brilliant. ${ }^{7}$

The actions of another ship captain soon increased the interest of the Grant administration in Samoan affairs. Commander Richard W. Meade 
of the U. S. Navy signed a treaty with the chiefs of Tutuila in February I872, granting the United States an exclusive right to a naval station at Pago Pago. In return for this privilege, Meade promised that the United States would extend its protection to the Samoans. Meade's action was taken without consultation with his superiors or instructions from the administration, and although Grant urged the Senate to ratify the treaty (with modification of the protectorate clause), the Senate refused even to consider the matter. ${ }^{8}$ Grant then resorted to sending a special agent to Samoa, Colonel Albert B. Steinberger, to keep an eye on affairs in the islands and to impress the Samoans with the continuing interest of the United States in their happiness and welfare. Steinberger's subsequent activities in Samoa, where he established himself as virtual premier, won for the United States the great esteem of the Samoans and led indirectly to the 1878 treaty between Secretary of State William M. Evarts and the Samoan envoy Le Mamea. ${ }^{9}$

What is less well known about American interest in Samoa during the Grant administration is the extent to which American officials predicated their actions upon their belief in the future importance of Samoa. President Grant, always an exponent of insular expansion, spoke glowingly in his 1872 message on the Meade treaty of "the advantageous position of Tutuila." 10 Commander Meade himself was strongly influenced by instructions from the American minister at Honolulu, Henry A. Pierce, who had written to him to clarify the objects of his South Seas cruise before he sailed for Samoa. "It is of great importance to the future interests of our country in the South Pacific," said Pierce, that Meade should proceed as soon as possible to Samoa to promote American interests "present and contemplated" there. Pago Pago was by far the best and most commodious harbor in the South Seas, and would soon be the site of a coaling station for steamships operating between San Francisco and Australia. "In view of the future domination of the U. States in the N. \& S. Pacific Oceans," it was extremely important that Samoa should be under American control.11

Minister Pierce clearly envisioned a great destiny for the United States in the Pacific. What is more telling, however, is that Grant's able Secretary of State, Hamilton Fish, also presumed Samoa's future importance and acted on it. In his initial instructions to Colonel Steinberger in 1873 , Fish pointed out that "it is not unlikely that perhaps in the not distant future the interests of the United States may require not only a naval station in the Samoan group, but a harbor where their steam and other vessels may freely and securely frequent." Steinberger was to provide the government with full and accurate information on 
Samoan affairs in order to facilitate the United States securing a harbor there. ${ }^{12}$

Secretary Fish was no less certain of Samoa's potential value to the United States when he wrote his 1874 instructions to Steinberger, prior to the latter's second voyage to the islands. But in this instance, Fish was more cautious as regarded the possibility of action in the near future. "It is more than doubtful," he told Steinberger regretfully, " ... whether these considerations would be sufficient to satisfy our people that the annexation of those islands to the United States is essential to our safety and prosperity."13

Hence a number of important individuals in the United States government in the early 1870 os were already anticipating Samoa's future importance to the nation. Meade's abortive treaty of 1872 was largely the result of this anticipation. President Grant thought a naval station at Tutuila would be extremely advantageous. Secretary of the Navy Robeson urged in 1872 that a coaling station be established at Pago Pago. ${ }^{14}$ Most significant, Colonel Albert B. Steinberger was dispatched to Samoa mainly because, as Secretary Fish put it, the interests of the United States "in the not distant future" might require a naval base and a harbor for merchant vessels in the Samoan group. Samoa was important for the role it was to play in the future rather than for its present status. The vision of America's destiny in the Pacific was already beginning to encompass the islands of Samoa.

Samoa became of much greater importance to the United States in the 1880 s, as several European powers relentlessly swallowed up the other island kingdoms of the South Pacific. France took Tahiti in I 880 and the New Hebrides in 1886 . Great Britain, which had claimed Fiji in 1874 , ten years later divided up New Guinea with Germany. Spain took the Carolines in 1885 . And Germany moved into the Solomons and the Marshall Islands in 1886 . The United States was well aware of what was occurring in the South Pacific, and of the implications for the American foothold at Samoa. In 1888, Secretary of State Thomas F. Bayard reminded the American minister at Berlin, G. H. Pendleton, that as a result of recent European advances in the area, "of the vast aggregate of territory in the Pacific Ocean, but a few island groups . . . remain today as independent and autonomous." In view of this fact, Bayard told Pendleton, "it is necessary to emphasize the importance attached by this Government to the maintenance of the rights to which the United States has become entitled in any of the few remaining regions now under independent and autonomous native governments in the Pacific Ocean."15 Samoa, in addition to being strategically located and in possession of a superb harbor, was the last island group in the 
South Pacific where the United States had a political foothold. Because the United States was to play such an active role in future developments in the Pacific, Samoa could not be allowed to fall to a European rival.

A belief in the archipelago's eventual value, in combination with the continuing opposition of American public and congressional opinion to overseas expansion, largely determined the history of American involvement in Samoa for the remainder of the century. It was obvious, after the multitude of frustrations suffered by the expansionists Seward and Grant, that the national opinion would not allow the United States to acquire territory in or extend its protection to Samoa. On the other hand, a succession of administrations in Washington was unwilling to see Samoa fall to another power: to Germany, which had the largest commercial stake in the islands, or to Great Britain, which was being pressured by New Zealand to acquire Samoa in order to protect the northern approaches to New Zealand itself. The natural policy for the United States to follow in these circumstances was one of maintaining Samoan independence until public opinion had been converted to an acceptance of expansion. The United States would seek to maintain the status quo in the islands, sustaining the American presence there and preventing Samoa from falling into British or German hands, until the American public would sanction at least the acquisition of Pago Pago. The course of events subsequent to Steinberger's mission demonstrates that this was indeed the policy followed by the United States.

In 1877, the Samoan envoy Le Mamea arrived in Washington to request either annexation of the islands or an American protectorate. $\mathrm{He}$ was referred to Assistant Secretary of State Frederick W. Seward, son of the famed expansionist, who told him that the American people, unfortunately, had changed their opinion of expansion since the great years of Manifest Destiny in the 1840 os and 1850 . They now looked with disfavor on schemes for extending the national boundaries. Seward "believed this dread of national expansion was a passing phase," but he recognized that "while it lasted, it had to be reckoned with." President Hayes, Secretary Evarts, and the rest of the Cabinet told Le Mamea the same thing: Samoa could not be annexed, nor could a protectorate be extended, because the Senate would not consent to any treaty that cost the government money or placed it under an obligation. ${ }^{16}$

It was important, however, that something be done at this time to protect the American position in Samoa. The islands were in constant turmoil, with rival chiefs vying incessantly for the throne. The near anarchy in the islands presented the Germans and the British with a convenient pretext to seize control. To head off such a development, the American consul at Apia, Gilderoy W. Griffin, was instructed in July 
1877 to do all in his power "to aid in maintaining a good and permanent government on the Islands." 17 The greatest threat to Samoan independence came from Great Britain, which was still under pressure from the New Zealanders to seize the islands.

Apparently because Washington was concerned with maintaining Samoan independence, Le Mamea's mission to the United States resulted in the treaty of 1878 between the kingdom of Samoa and the government of the United States. ${ }^{18}$ The United States was granted rights - though not exclusive rights - to a naval station at Pago Pago; in return, the United States agreed to extend its "good offices" in any dispute between Samoa and a third government. A New York Times editorial published a few weeks after the signing of the treaty suggested that the major reason it was entered into was "to anticipate the diplomatic flank movement of Sir Arthur Gordon, Governor of Fiji," for the annexation of Samoa to the British Empire. "The intrinsic importance of the naval and supply station acquired by the treaty, and the precedent it creates in our history as a nation," concluded the editorial, "will cause its practical attainment to be watched for with curiosity and interest."19

The United States thus stood ready from 1878 on to claim a voice in any dispute between Samoa and the government of Great Britain or Germany. While the "good offices" clause of the 1878 treaty did not in any way obligate the United States to act, it is remarkable, considering the temper of the Times, that such a treaty could have been ratified unanimously by the Senate. It is significant that in 1878 the only other American treaties that included "good offices" clauses were the two with China and Japan, both signed in 1858 . Also, it should be noted that the only additional "good offices" treaty signed and ratified by the United States in the entire 19 th Century was the 1882 treaty with Korea. ${ }^{20}$ Thus all four such treaties were with countries that looked out on the Pacific. Here was another indication of America's concern with that part of the world.

During the late 1870 s and early 1880 , America's interest in Samoa steadily increased, while the policy of maintaining the Samoan status quo continued in operation. In September of 1879 the United States commitment was expanded when Consul Thomas M. Dawson, acting on his own authority and in concert with the American naval officer on duty at Apia, entered into a municipal convention with the German and British representatives for tripartite control of the Apia district. Dawson's explanation for his action was to the point. If he and Captain Chandler had not acted, he informed Washington, "Chaos and Anarchy would have assumed sway once more in Apia," presenting the British with a justification for acting alone and gaining an advantage that would have 
led to a British-controlled Samoa. "It seemed much better, therefore, to share than to lose all interest in the ... foreign authority exercised here." It was Dawson's conviction that he would have been "severely censured" by the State Department if he had allowed the United States "to lose an equal part in the control of affairs here with other Governments." ${ }^{21}$ A better statement of American policy in Samoa could hardly be hoped for. Dawson's conduct in connection with the municipal convention was approved by the State Department. ${ }^{22}$

Such entanglements were out of all proportion to the tiny American commercial interest that existed in Samoa throughout the period. Exports to the islands of the Pacific, including Australia and New Zelaand, amounted to less than 14 million dollars in 1885 , and only slightly more than 16 million in 1890 . This was in comparison to 600 million dollars worth of exports to Europe in 1885 and 21 million dollars worth to Asia, and to 683 million dollars worth to Europe in 1890 and 20 million dollars worth to Asia. The high point of Pacific exports was not reached until 1899 , and even then less than 30 million dollars worth of American goods were shipped to the Pacific, compared to 936 million dollars worth to Europe and 49 million dollars worth to Asia. Imports from the Pacific throughout the period were even smaller. ${ }^{23}$ As for Samoa itself, net exports of American goods to the islands in 1886 amounted to just $\$ 150,000$, and in 1887 only six American vessels delivered cargoes to Apia. ${ }^{24}$ Yet Americans continued to speak glowingly of Samoa's commercial value. Gustavus Goward, the United States commercial agent at Pago Pago, reported to Assistant Secretary of State Seward in 1878: "The Samoan archipelago is now, by reason of its geographical position in the center of Polynesia, lying in the course of vessels from San Francisco to Auckland, from Panama to Sydney, and from Valparaiso to China and Japan . . . the most valuable group in the South Pacific." Goward thought that a naval station at Pago Pago would give the United States control of a large part of Polynesia. This was a matter of such paramount importance to the economy of the West Coast of the United States, he concluded, that businessmen there should take an active interest in Samoan affairs. ${ }^{25}$ Even more positive about Samoa's future commercial importance was Consul George H. Bates, who had been sent to Samoa in 1886 by Secretary Bayard to investigate conditions there. Bates informed Bayard that Samoa was as important to the future commerce of the South Pacific as Hawaii was to the North Pacific. Once the anticipated interoceanic canal was dug across the isthmus of Panama, Hawaii and Samoa would be the two keys to "maritime dominion in the Pacific." Bates went on to urge that the United States government connect itself "indissolubly" with Samoa so as to forestall the possibility 
of losing the opportunity to control the future commerce of the Pacific, "which . . . must, from the immense number of inhabited islands alone, be of such magnitude as will make all present conjectures seem but trifling." He concluded with an admonition that the United States keep a sharp eye out to protect its position in Samoa: "Having . . . so long ago acquired this foothold in the South Pacific, it would be short-sighted indeed if we were to permit the advantage of this action to slip away from us by leaving the way open to European domination in this group." 26

At the same time that some Americans were looking forward to Samoa's future commercial value, the navy was also taking a deeper interest in the archipelago. In 1880 and 1889 cargoes of coal were delivered to Pago Pago to testify to American treaty rights. ${ }^{27} \mathrm{~A}$ survey of the reports of the Navy Department from Grant to McKinley reveals that Samoa, Hawaii, the isthmian canal, the Midway Islands, and, after the war with Spain, Wake, Guam, and Manila, were all closely interrelated in the minds of naval planners. Theodore Roosevelt, three years before he entered the Navy Department, connected Samoa with an isthmian canal, a base at Hawaii, and a big navy. ${ }^{28}$ Commodore Robert W. Shufeldt, the man who opened up Korea to American penetration in 1882 , wrote to Navy Secretary Thompson two years earlier expressing his belief that "the acquisition of Alaska and the Aleutian Islands, the treaties with Japan, Sandwich Islands and Samoa, are only corollaries to the proposition that the Pacific Ocean is to become at no distant day the commercial domain of America." 29 When that day came, a base at Pago Pago, to protect the trade routes to the South Pacific and to help defend the western approaches to the canal, would be a necessity.

By 1886 , however, it was evident that only strong and decisive action by the United States could prevent a European rival from seizing Samoa. Germany, newly hungry for colonies, had intervened aggressively in Samoan politics. The native king, Malietoa Laupepa, had been driven from the seat of government, and one Tamasese set up as pretender to the throne. German marines had hauled down the Samoan flag in the face of the protests of the British and American consuls. Fearing the imminent annexation of the islands by Germany, or at least the establishment of a German protectorate, President Grover Cleveland and Secretary Bayard decided to act. Minister Pendleton at Berlin was cabled to demand from the German government assurances "that Germany seeks no exclusive control in Samoa." The United States expected Germany to do nothing in Samoa to impair American rights under the I 878 treaty. ${ }^{30}$ With this cable, the United States government was intervening directly for the first time in Samoan affairs. This intervention 
marked the first step leading up to the 1887 Washington Conference on Samoa.

The Washington Conference of June 25 to July $2 \hbar, \mathrm{I} 887$, attended by representatives of the United States, Great Britain, and Germany, accomplished nothing of enduring significance. The conference did, however, serve the obvious American purpose of forestalling any immediate German annexation of Samoa. Germany suspended hostilities in the islands and agreed, temporarily at least, to maintenance of the Samoan status quo. At the conference, however, Germany and Great Britain (which had reached a prior agreement with regard to Pacific and African colonies that included British support for a German mandate in Samoa) presented the United States with a united front in favor ot German control of the islands. Secretary Bayard resisted such a development adamantly, and the conference adjourned without a settlement having been reached. However, before the adjournment the American Secretary of State presented the German and British representatives with a clear picture of why the United States would not allow the Samoan Islands to slip into German hands. Both Germany and Great Britain already possessed a number of island outposts in the South Pacific, Bayard pointed out, while the United States, whose interest was "very great and quite equal to any other," had none. As for Samoa, Bayard declared "that the importance of these islands is mainly because of their geographical position. They lie in the pathway of a commerce that is just being developed." He connected Samoa with the Pacific coast and isthmian trade of the United States. "The opening of the west coast of North America to civilization and commerce by means of the transcontinental railways," he declared, "had given to this group of islands an interest which they never had before, and, moreover, we all hope for the penetration of the isthmus in some way or other. If that occurs, a new feature of interest will be added to them." The Secretary's final words on the subject further indicate the strategic and commercial importance which the United States expected Samoa to acquire at some time in the near future: "There is something beyond the mere material present value of the land or the products, and it was for that reason that the United States desired to see that group of islands maintained for the common use of nations." 31

American concern for Samoa's continued independence was hardly assuaged by the fruitless outcome of the Washington Conference. Nor was the situation helped by the resumption of German interference in Samoan affairs in the aftermath of the conference. Malietoa Laupepa was deported from his little kingdom, and the German puppet Tamasese, supported by German warships and 700 German marines, set about 
solidifying his hold on the throne. In the late summer of 1888 a new revolt broke out in the islands, led by a chieftain named Mataafa. While most of the American press spoke out against further involvement of the United States in these far-off islands, certain newspapers began to demand action. The Atlanta Constitution warned of a German scheme aimed at "crowding us out of what promised to be a very valuable trading post." The Philadelphia Press predicted that failure to act now would "probably be a matter of regret" fifty years hence, "when the United States, China, and Australia divide the Pacific."32 Forceful German incursions on Samoan independence continued through I888, however, despite American protests. On January 5, I889, a cable was received in Washington from the American consul at Apia. The cable reported a bloody clash between German sailors and Mataafa's rebels, which had left twenty Germans dead and thirty wounded. The outraged Germans had sworn vengeance and were "shelling and burning indiscriminately." They were not respecting the rights of American nationals. A naval squadron was requested. ${ }^{33}$

The situation in Samoa in January 1889 made it encumbent upon the United States to act if it wished to forestall again German annexation of the archipelago. Two steps were taken by the Cleveland administration in this direction. The warship Trenton was dispatched to Apia; and the President, long an opponent of American overseas expansion, sent a message to Congress placing the whole annoying Samoan problem in the hands of the legislative branch. Cleveland communicated to the Congress in strong terms his own view that "the autonomy and independence of Samoa should be scrupulously preserved." In addition, he reminded that body that the Samoan archipelago lay "in the direct highway of a growing and important commerce between Australia and the United States." ${ }^{34}$ Even Grover Cleveland, apparently, was aware of the potential of Samoa as a stepping-stone to the entrepots of the South Pacific.

In the ensuing Senate debates, the subject of Samoa's ultimate role in an American-dominated Pacific was brought up time and again. John Sherman of Ohio urged that the United States not give up its hard-won foothold at Pago Pago. ${ }^{35}$ Senator William P. Frye of Maine contended that once the isthmian canal was built, Samoa would be "of infinitely greater importance to our interests" than Hawaii, because of Samoa's supposed position "exactly in line" between the isthmus and Asia and Australia. ${ }^{36}$ John H. Reagan of Texas demanded that his colleagues consider not just the present value of Samoa to the United States, but "what our future interests . . . may be." The Central American isthmus would soon be pierced, Reagan said, bringing "the people of the islands 
of the Pacific into closer relations with ... the people of the United States. . . . Our relations to them commercially and geographically make it to our interest that the control of the islands of the Pacific should not be absolutely absorbed by the powers of Europe." 37 The most outspoken advocate of a tough policy in Samoa, however, was Senator Joseph N. Dolph of Oregon, who went so far as to suggest that the Monroe Doctrine be extended to encompass Samoa. Someday, Dolph asserted, China, Japan, Australia, and the islands of the Pacific would be the commercial neighbors of the west coast of the United States. "It is difficult now to conceive of the vast fleet of merchant vessels which will be required for the extensive commerce which will spring up in the near future," he said, "when these islands are peopled by the Caucasian race, the soil cultivated, and their resources developed." Because Samoa lay directly on the track of commerce from the west coast of the United States and from the isthmus to Asia and the South Pacific, it could not be allowed to pass under the control of any other power. Moreover, Samoa in German hands would put a German fleet thousands of miles closer to the west coast of the United States, and to the future interoceanic canal, than would otherwise be the case..$^{38}$

The outcome of the Congressional debates of January I889 was an appropriation of $\$ 500,000$ for the protection of American lives and property in Samoa, and another of $\$ 100,000$ for the development of the harbor at Pago Pago. President Cleveland's actions in submitting the Samoan affair to the Congress, meanwhile, had led to a determination by Bismarck that something be done to head off the threat of a confrontation between Germany and the United States. The Germans suspended hostilities against Mataafa, and a new conference on Samoa was called to meet at Berlin in late April. Cleveland and Bayard accepted Bismarck's proposal for a tripartite conference. It was left to the incoming Republican administration of Benjamin Harrison, with Harrison's Secretary of State James G. Blaine, to determine the American position at Berlin.

Even more than that of Cleveland and Bayard, the attitude of Harrison and Blaine toward the Samoan problem was based upon an appreciation of America's future role in the Pacific. In his instructions to the American commissioners to the Berlin Conference, Secretary Blaine, always an advocate of an expansive American foreign policy, declared that "the interests of the United States require the possession of a naval station in these remote parts of the Pacific." American commerce with Asia was developing "largely and rapidly," and "the certainty of an early opening of an Isthmian transit from the Atlantic to the Pacific (under American protection) must create changes in which no power can be more directly interested than the United States." Because of its dawning preeminence 
in the area, "in any question involving present or future relations in the Pacific, this Government can not accept even temporary subordination." No regime could be instituted in Samoa which threatened to check the development of a strong American presence there. ${ }^{39}$

The end result of the 1889 Berlin Conference was the Act of Berlin, by which the three powers agreed to a tripartite protectorate over Samoa. ${ }^{40}$ The United States thereby entered into a pact that ran counter to the whole American tradition of shunning entangling alliances. The explanation is that in 1889 joint control was seen to be the only way to forestall the islands' falling under the exclusive dominion of Germany. Since the United States was not willing to see that happen, the Harrison administration was forced to accept tripartite control as the only feasible alternative.

The remainder of the story of American involvement in Samoa in the last years of the igth Century can be quickly told. As American wealth and power grew in the 1890 s, the American presence at Samoa increasingly came to fit into a larger pattern of American military and commercial interests in the Pacific. Grover Cleveland, back again in the White House, grew tired of the continuing instability in the islands under the new government. Pointing to "the impolicy of entangling alliance," he twice recommended to the Congress that the United States withdraw from the tripartite protectorate. ${ }^{41}$ But on both occasions the Congress ignored Cleveland's advice. A number of senators and congressmen lashed out at even the suggestion of withdrawal, citing in almost every instance Samoa's future importance to American interests in the Pacific. Representative W. F. Draper of Massachusetts warned that the United States was "the only great power interested in the Pacific trade which has not had the wisdom to acquire territory in localities where the great trade of the future will need guarding and supplying." To protect such trade, Draper urged the acquisition of naval bases at Samoa, Hawaii, the western terminus of the proposed canal, and at the Straits of Magellan. From these bases, he concluded, "a properly organized fleet . . . will hold the Pacific as an American ocean, dominated by American commercial enterprise for all time." 42 The expansionist Senator Henry Cabot Lodge also was certain of Samoa's importance as a strategic linchpin in the overall pattern of an American Pacific empire. In an 1895 article castigating the foreign policy of the Cleveland administration, Lodge declared that Samoa, while less important than Hawaii, was still of serious consequence to American military and commercial interests in the Pacific. "The wisdom of maintaining not only a naval station, but our commercial influence in the Samoan group, has long been apparent," he said. In Lodge's view, an American naval and 
commercial presence at Samoa was closely associated with an isthmian canal, and with bases at Hawaii and in the Caribbean. The canal should be built, Lodge asserted; and for its protection "at least one strong naval station" should be established in the Caribbean. For the defense of the canal in the west, and "for the sake of our commercial supremacy in the Pacific we should control the Hawaiian Islands and maintain our influence in Samoa."43 While Lodge was expressing these sentiments, Henry C. Ide, the former Chief Justice of the Samoan Supreme Court, was seeking to inform the American public as to the country's stake in Samoa. "Samoa stands as a sentinel and outpost in the vast southern sea, just as Hawaii does in the northern," Ide wrote. "If it is appropriated by any foreign power we have no foothold left south of the equator." The commercial future of the Pacific was "measureless," and Samoa was to serve as a vital element in securing the trade of that immense region for the United States. Finally, as coal was treated as a contraband of war, and since modern warships were absolutely dependent on coal supplies, unless the American grasp on Pago Pago was retained the whole of the South Pacific would be closed to the United States the instant war was declared by any naval power. ${ }^{44}$

The Spanish-American War and the imperialist surge that followed brought the culmination of the policy the United States had been pursuing in Samoa for twenty years. Since the 187os, the United States had been seeking to thwart any annexation of the islands by a European power until American public opinion was ready to approve the acquisition of the harbor of Pago Pago by the United States. By the end of the century, the American public, its appetite for insular expansion whetted by the acquisition of Puerto Rico, Guam, and the Philippines, was prepared to sanction such a move. This change in public opinion explains the ease with which the McKinley administration secured Senate approval of the 1899 treaty by which Germany and the United States divided the islands between them, the island of Tutuila, with its harbor of Pago Pago, going to the United States. ${ }^{45}$ President McKinley, in his Annual Message of 1899 , had high praise for the terms of the treaty. "To relinquish our rights in the harbor of Pago Pago, the best anchorage in the Pacific," the President declared, "was not to be thought of either as regards the needs of our Navy or the interests of our growing commerce with the East." ${ }^{66}$ McKinley's Secretary of State, John Hay expressed comparable satisfaction. "Our interest in Pago Pago," he told the American ambassador in London, "... was of the most vital importance. It is the finest harbor in the Pacific and absolutely indispensable to us." 47 
Since President Grant sent Meade's treaty of 1872 to the Senate for ratification, then, a succession of American officials had believed that the future welfare of the United States would somehow be affected by what happened in Samoa. Though the immediate interests of the United States in the South Pacific were infinitesimal throughout the period, the conviction persisted that one day soon the area would be the scene of tremendous political and commercial events. The destiny of the United States, its future economic greatness and its success against jealous rival powers, would be determined in the vast expanses of the western ocean. This belief in Pacific Destiny explains why the United States for over a quarter-century was so deeply involved in the affairs of far-off and seemingly insignificant Samoa.

\section{NOTES}

1 The standard account of the United States in Samoa is still George H. Ryden, The Foreign Policy of the United States in Relation to Samoa (New Haven, 1933). See also Sylvia Masterman, The Origins of International Rivalry in Samoa, I845-1884 (Stanford, 1934); Joseph Ellison, Opening and Penetration of Foreign Influence in Samoa to 1880 (Corvallis, Oregon, 1938); R. P. Gilson, Samoa, 18.30-1900: The Politics of a Multi-Cultural Community (Melbourne, 1970).

2 The Act of Berlin was referred to in this way by President Cleveland in his Annual Messages of 1893 and 1894 , and by Secretary of State Walter Q. Gresham in an 1894 report to the Senate. James D. Richardson (ed.), A Compilation of the Messages and Papers of the Presidents (20 vols.; New York, 1897-r917), XII, 5871, 5963; Papers Relating to the Foreign Relations of the United States, I894, Appendix I (Washington, 1895), 504 .

3 Thomas A. Bailey, A Diplomatic History of the American People (New York, 1969), 426. Julius W. Pratt, A History of United States Foreign Policy (Englewood Cliffs, New Jersey, 1955), 33I, wonders at the "almost neurotic intensity" with which the United States pursued its rivalry with Germany in Samoa. Samual Flagg Bemis, A Diplomatic History of the United States (New York, 1955), 456, apparently believes that American policy was motivated by an "executive ambition for Pacific naval bases." Richard W. Leopold, The Growth of American Foreign Policy (New York, 1962), 140, observes that Samoa "clearly ... lay beyond the defense perimeter of the United States." Alexander DeConde, A History of American Foreign Policy (New York, 1971), 322, states "the United States had no vital interest in the islands."

${ }^{4}$ George E. Baker (ed.), The Works of William H. Seward (5 vols.; New York, 1853 1884), I, 250. For an interesting essay on the theme of Pacific Destiny, see Dan Elbert Clark, "Manifest Destiny and the Pacific," Pacific Historical Review, I (1932), I-17.

${ }^{5}$ For the Wilkes treaty of 1839 with the Samoan chieftains, see Hunter Miller (ed.), Treaties and Other International Acts of the United States of America (8 vols.; Washington, 1931-1948), IV, 24I-244.

6 The role of commercial interests in involving the United States in Samoa is discussed by Barry Rigby, "Private Interests and the Origins of American Involvement in Samoa, 1872-1877," Journal of Pacific History, VIII (1973), 75-87.

'Wakeman to Webb, September 20, 1871, House Executive Documents, 44th Cong., rst Sess., No. 16r (Serial i691), 7, ro. 
${ }^{8}$ For a copy of Meade's treaty, with Grant's message recommending ratification, see ibid., 6-7.

- On Steinberger, see Joseph W. Ellison, "The Adventures of an American Premier in Samoa, 1874-1876," Pacific Northwest Quarterly, XXVII (1936), 31 1-346.

${ }^{10}$ House Executive Documents, 44th Cong., Ist Sess., No. I6r (Serial r69r), 6.

${ }^{11}$ Pierce to Meade, January 19, 1872, Ryden, Foreign Policy in Relation to Samoa, 60.

${ }^{12}$ Fish to Steinberger, March 29, 1873, House Executive Documents, 44th Cong., ist Sess., No. 16r (Serial r69r), 5 .

${ }^{13}$ Ibid., 76.

${ }^{14}$ Report of the Secretary of the Navy, 1872 (Washington, 1872), 13.

${ }^{15}$ Bayard to Pendleton, January 17, 1888, Congressonal Record, 5oth Cong., 2nd Sess., I333 (January 20, I889).

${ }^{16}$ Frederick W. Seward, Reminiscences of a War-Time Statesman and Diplomat (New York and London, 1916), 439.

${ }^{17}$ Instructions to Consuls, to Griffin, July 5, 1877, Ryden, Foreign Policy in Relation to Samoa, 172 .

${ }^{18}$ William M. Malloy (ed.), Treaties, Conventions, International Acts, Protocols and Agreements between the United States of America and Other Powers, I776-1909 (2 vols.; Washington, I910), II, I 574-I 576.

19 New York Times, April 10, 1878.

${ }^{20}$ For the Chinese, Japanese, and Korean treaties, see, respectively, Malloy (ed.), Treaties, I, 21 I-221; I, 1000-1010; I, 334-340.

${ }^{21}$ Consular Dispatches, from Dawson, September 13, 1879, Ryden, Foreign Policy in Relation to Samoa, 238.

${ }^{22}$ Instructions to Consuls, to Dawson, January 15, 1880 , ibid., 244.

${ }^{23}$ U. S. Bureau of the Census, Historical Statistics of the United States, $1789-1945$ (Washington, 1945), 250-25I.

${ }^{24}$ Foreign Relations, 1894, Appendix I, 509.

${ }^{25}$ Goward to Seward, December 28, 1878, Senate Executive Documents, 46th Cong., Ist Sess., No. 2 (Serial 1869 ), 29.

${ }^{26}$ Bates to Bayard, December 10, 1886, Foreign Relations, 1889 (Washington, 1901), 287.

${ }^{27}$ Masterman, Origins of International Rivalry in Samoa, 151; Report of the Secretary of the Navy, 1889 (Washington, 1889), 31 .

${ }^{28}$ Roosevelt to Anna Roosevelt, May 20, 1894, Elting E. Morison (ed.), Letters of Theodore Roosevelt (8 vols.; Cambridge, Mass., I95I-I954), I, 379.

${ }^{29}$ Charles O. Paullin, Diplomatic Negotiations of American Naval Officers, $1778-1883$ (Baltimore, 1912), 302.

${ }^{30}$ Bayard to Pendleton, January 12, 1886, House Executive Documents, 5oth Cong., Ist Sess., No. 238 (Serial 2560), 15.

${ }^{31}$ Protocol of second Samoan conference, Washington, July 2, 1887, Senate Executive Documents, 5oth Cong., 2nd. Sess., No. 102 (Serial 2612), 12.

32 Public Opinion, IV (October I 887-April I 888), 7, III (April I887-October 1888), 55 I.

${ }^{33}$ Blacklock to Bayard, January 5, 1889, Senate Executive Documents, 5oth Cong., 2nd Sess., No. 68 (Serial 2611), 17.

${ }^{34}$ Richardson (ed.), Messages and Papers of the Presidents, XI, 5930.

${ }^{35}$ Congressional Record, 50th Cong., 2nd Sess., 1290 (January 29, 1889).

${ }^{36}$ Ibid., 1374 (January 31, 1889).

37 Ibid., 1337 (January 30,1889 ).

${ }^{38}$ Ibid., 1334, 1332, 1337, 1333 (January 30, 1889). 
${ }^{30}$ Blaine to Kasson, Phelps and Bates, April I I, 1889 , Foreign Relations, 1889 (Washington, 1890), 201.

${ }^{40}$ Malloy (ed.), Treaties, II, I 576-1589.

${ }^{41}$ Richardson (ed.), Messages and Papers of the Presidents, XII, 5963-5964, 6067.

42 Congressional Record, 53rd Cong., 2nd Sess., 1893-1894 (February 3, 1894).

${ }^{43}$ Henry Cabot Lodge, "Our Blundering Foreign Policy," Forum, XIX (1895), 10, 17.

${ }^{44}$ Henry C. Ide, "Our Interest in Samoa," North American Review, CLXV (1897), r6r. See also Ide's article "The Imbroglio in Samoa," ibid., CLXVIII (1899), 679-693.

${ }^{45}$ Malloy (ed.), Treaties, II, 1595-1597; Foreign Relations, 1899, 667-668.

${ }^{46}$ Richardson (ed.), Messages and Papers of the Presidents, XIII, 6376.

47 Hay to Joseph Choate, November $\mathrm{I}_{3}, 1899$, William R. Thayer, Life and Letters of John Hay (2 vols.; Boston and New York, 1915), II, 282. 